\title{
Lumen
}

Selected Proceedings from the Canadian Society for Eighteenth-Century Studies

\section{Mary Wollstonecraft and Hannah More: Politics, Feminism and Modern Critics}

\section{Claire Grogan}

Volume 13, 1994

URI : https://id.erudit.org/iderudit/1012525ar

DOI : https://doi.org/10.7202/1012525ar

Aller au sommaire du numéro

Éditeur(s)

Canadian Society for Eighteenth-Century Studies / Société canadienne d'étude du dix-huitième siècle

ISSN

1209-3696 (imprimé)

1927-8284 (numérique)

Découvrir la revue

Citer cet article

Grogan, C. (1994). Mary Wollstonecraft and Hannah More: Politics, Feminism and Modern Critics. Lumen, 13, 99-108. https://doi.org/10.7202/1012525ar 


\section{Mary Wollstonecraft and Hannah More: Politics, Feminism and Modern Critics}

Miss Berry's diary entry for Tuesday 2 April 1799 reads:

In the many hours I have spent alone this last week, I have been able... to go entirely through Hannah More, and Mrs Woolstonecroft [sic] immediately after her. It is amazing, or rather it is not amazing, but impossible, they should do otherwise than agree on all the great points of education.

Numerous modern critics use this diary entry to support their argument that little separates the feminist content in the works of Mary Wollstonecraft (Thoughts on the Education of Daughters [1787], A Vindication of the Rights of Woman [1792]) from that in the works of her contemporary Hannah More (Essays [1777], Strictures on Female Education [1799]). This desire to assimilate the educational beliefs of More and Wollstonecraft surfaces in Mitzi Myers' article "Reform or Ruin": A Revolution in Female Manners' (199-216), in Kowaleski-Wallace's book Their Father's Daughters: Hannah More and Maria Edgeworth, and the Patriarchal Complicity (6-9), and in Anne Mellor's book Romanticism and Gender (220, n. 12). While Janet Todd (Sign of Angellica [211]), Alice Browne (The EighteenthCentury Feminist Mind [105]), Gerald Newman ('Anti-French Propaganda and British Liberalism in Early Nineteenth Century' [385-418]) and Jane Moore ('Promises, Promises: the Fictional Philosophy in Mary Wollstonecraft's Vindication of the Rights of Woman' [158-61]) all stress the similarities between these two writers.

I argue that the desire (and apparent ability) to create a common ground between politically opposing positions over-simplifies and misrepresents the sophistication of the views actually presented. Views which constitute part of the debate in the revolutionary period about the female sex's social, economic, and political role. When Berry continues, 'Hannah More will, I dare say, be very angry when she hears this, though I would lay a wager that she never read the book' (91-92), she indicates her awareness that More is an anti-Jacobin writer (a supporter of the established system: church, crown, court, parliament) while Wollstone- 
craft is an English-Jacobin writer (a supporter of new revolutionary principles: reform of the political, legal, and economic system).

Some modern critics' attempts not only credit the works of Wollstonecraft and More with a similar feminist agenda but even assert that More's works are more stridently feminist in nature than Wollstonecraft's. For example, Gerald Newman writes 'More did more to subvert the established order than to uphold it' (401) while Myers concludes that 'More was a female crusader infinitely more successful than Wollstonecraft or any other competitor' because 'her text is alive with submerged power' (339-40). Both these quotes fail to acknowledge that More's reforms aim to teach the female reader to accept her secondary position in society and are thus modifications within the existing patriarchal order. More endeavours to implement changes that invest the domestic sphere with moral worth but she falls well short of claiming political Rights or liberties for her sex. She voices her assurance in Memoirs and Correspondence that 'there is no animal so much indebted to subordination for its good behaviour as woman' and that they 'already have more liberty than is good for them' (2: 372).

In contrast Wollstonecraft voices her dissatisfaction with the subordinate position of females and demands greater Rights and liberties for them. She outlines an improved education as the means to achieve necessary reforms. While More's text might be perceived by the twentieth-century critic to be 'alive with submerged power,' Wollstonecraft's text has a stated feminist agenda to bring about a 'REVOLUTION in female manners' and promote a 'differently constituted society' in which the sexes will be equal (Vindication 92). While Wollstonecraft and More agree that the prevailing system of education tends to weaken the principles it ought to strengthen' (Strictures 1: 62-3; ch.2), their different political affiliations dictate distinct educational programs. A close textual analysis of what each writer hopes to achieve through her educational reforms illustrates the strikingly different types of female they hope will emerge from the revolutionary era.

Both More and Wollstonecraft wish to educate females to expect and to demand more than a purely ornamental role in life. They present education, especially reading, as a crucial step in any development of the female character and so they try to guide their readers towards suitable reading material. However, their policies about suitable material and about censorship differ from each other because of their underlying beliefs about female intellect. More repeatedly asserts that 'there is a different bent of understanding in the sexes' (Essays 11) because gender determines intellect, social and moral duties. While Wollstonecraft asserts that as 'there is no sex in the mind or soul' (Vindication 106), there is no reason why females should not be educated out of their subordinate 
and intellectually inferior position. For these reasons, comments by modern critics such as Jane Moore that More and Wollstonecraft concur on appropriate texts need to be carefully assessed since she uses Locke's Treatise on Education as her only example (161). Equally Myers's sweeping comment that both writers 'go in for dry, tough reading' does not bear close scrutiny because she fails to note that Wollstonecraft and More have differing ideas about what actually constitutes 'dry, tough reading'.

A focus on Wollstonecraft's and More's criticisms of novel reading clearly reveals their respective political bias and the distance between their positions in the debate over Women's Rights. More and Wollstonecraft both blame novel reading for much female foolishness because of content, the misdirected use of time, and the passive reading habits novels encourage. They use their criticisms of novels to raise three important aspects of the female character; namely, her duties, her sensibility, and her conversational abilities. While they concur that these are drawbacks to novel reading, they do so for different reasons and suggest widely different courses of remedial action.

As both More and Wollstonecraft agree that reading should not be just another accomplishment with which to dazzle male society, their initial comments appear very similar. For instance Wollstonecraft states:

Novels, music, poetry, and gallantry, all tend to make women the creatures of sensation, and their character is thus formed in the mould of folly during the time they are acquiring accomplishments. (Vindication 130)

In a similar vein More argues

[Novels]... by their very nature and constitution... excite a spirit of relaxation, by exhibiting scenes and ideas which soften the mind and let the fancy at work; they impair its general powers of resistance, and at best feed habits of improper indulgence, and nourish a vain and visionary indolence, which lays the mind open to error and the heart to seduction. (Strictures 1: 181; ch. 7)

Despite the fact that both women agree novels have undesirable results, the reasons behind their criticisms of the genre are poles apart since they hope to replace this ornamental individual with a strikingly different female. More promotes the new domestic female while Wollstonecraft promotes a new political one. The former despises novels because they do not educate a female about her domestic duties, while the latter despises them for the seductive but disempowering lifestyle they suggest to the reader. Wollstonecraft warns that novel readers 
are women who are amused by the reveries of the stupid novelists, who... work up stale tales... which equally tend to corrupt the taste, and draw the heart aside from its daily duties. (Vindication 425-26)

More complains:

Merely ornamental accomplishments will but indifferently qualify a woman to perform the duties of life, though it is highly proper she should possess them, in order to furnish the amusements of it. (Essays 131-32)

Thus both deplore novel-reading as it distracts a female from her real duties, but they differ over what constitutes her real duties. While Myers asserts that Wollstonecraft 'no more than More aspires to pluck most women out of their families or dissever them from their relative duties' (208) she fails to examine what duties are being referred to. More's 'duties of life' are domestic duties dictated by the church: '[Females] are of a religion which does not impose penances, but enjoins duties' (Essays 35). Duties More sums up as 'religious reading... active business... reflection... or self-examination' (Strictures 1: 182; ch. 7), since 'every kind of knowledge which is rather fitted for home consumption than foreign exportation, is peculiarly adapted to women' $(2: 3 ; \mathrm{ch}$. 13). The female's sphere is domestic and private while the male's is public and foreign. Indeed the 'chief end to be proposed in cultivating the understandings of women, is to qualify them for the practical purposes of life' (2: 1; ch. 13).

The attitude of English-Jacobin writers such as Wollstonecraft to the question of duties is best explained by Mr. Francis's character in Mary Hays's novel Memoirs of Emma Courtney (1796):

Our Duties, then are obvious - if selfish and violent passions have been generated by the inequalities of society, we must labour to counteract them, by endeavouring to combat prejudice, to expand the mind, to give comprehensive views, to teach mankind their true interest, and to lead them to habits of goodness and greatness. (1:50)

Wollstonecraft accepts this manifesto and, while she does not reject the domestic side, she equally does not limit all a female's duties to those of a purely domestic nature:

But, fulfilling the duties of a mother, a woman with a sound constitution, may still keep her person scrupulously neat, and assist to maintain her family, if necessary, or by reading and conversations with both sexes, indiscriminately, improve her mind. (Vindication 443) 
In this way domestic concerns complement political and moral duties. Myers states that Wollstonecraft 'equates private need and public contribution' because she 'demands no rights without concomitant duties' (338). I read Wollstonecraft's argument to be that Rights bring with them certain duties which is distinct to More's position that the completion of duties entitles one to certain Rights. As Wollstonecraft explains:

The being who discharges the duties of its station is independent; and, speaking of women at large, their first duty is to themselves as rational creatures, and the next, in point of importance, as citizens, is that, which includes so many, of a mother. (331)

Wollstonecraft believes that the passive, conforming female advocated in More's educational treatises 'abstains, it is true, without any great struggle, from committing gross crimes; but how does she fulfil her duties?' (102). 'The private duty of any member of society must be very imperfectly performed when not connected with the general good,' a situation that arises because 'females are denied all political privileges' (426). The implications of Wollstonecraft's 'civil duties' become clearer when she states,

If women were led to respect themselves, if political and moral subjects were opened to them... I will venture to affirm, that this is the only way to make them properly attentive to their domestic duties. An active mind embraces the whole circle of its duties, and finds time enough for all. (Vindication 391)

In order to 'discharge civil duties... [a] female needs the protection of civil laws' (333). Until females are given political and moral status they will not perform their 'domestic duties' to the best of their ability. Indeed, 'take away natural rights, and there is of course an end of duties' (334).

Wollstonecraft argues that females have public and private roles to fulfil, while More renounces the public or political to claim the private or moral as distinctly feminine. Unlike More who describes females influencing national events through household behaviour (raising children, educating the poor, enforcing the socially ordained hierarchy), Wollstonecraft presents females being educated and emancipated by reading and then claiming political positions and jobs in the market place as members of society at large and not just in the microcosm afforded by the home. Wollstonecraft wants females to influence national events through direct intervention and participation. She argues that appropriate reading is the thin end of the wedge since it is a means of self-education which allows them to become full members of society. Once this is 
achieved other political and economic changes will naturally (though perhaps not comfortably) follow.

Despite their pernicious influence she refuses to ban novels but defends any reading over total ignorance and hence subordination:

Yet, when I exclaim against novels, I mean when contrasted with those works which exercise the understanding and regulate the imagination. - For any kind of reading I think better than leaving a blank still a blank. (Vindication 427)

Wollstonecraft continues, 'When, therefore I advise my sex not to read such flimsy works, it is to induce them to read something superiour [sic]' (Vindication 430). This is similar to a lady's comment 'On the Good Effects of Bad Novels' in the Lady's Monthly Magazine (1 October 1798): 'So, in the mind, idle tales first cling to a barren surface; they make, however, a little soil in which better things may grow' (qtd. in Taylor 259). Wollstonecraft encourages females to read because she acknowledges the power of the written word to open the reader's mind to new possibilities and lifestyles.

Thus, when Wollstonecraft and More both denounce Rousseau's argument that 'sensibility is nurtured at the expence [sic] of understanding' (Vindication 181), the modern reader should be alert to the different motives for similar criticisms. Wollstonecraft writes in a piece for the Analytical Review: "Throughout, sensation is termed sensibility; and vice, or rather sensuality, varnished over with a gloss, which the author seems to think virtue,' and 'this is the varnish of sentiment to hide sensuality' (3 [January 1789], 69), while More describes 'sentiment' in her Essays as 'the varnish of virtue, to conceal the deformity of vice' (78). More complains that sentimental novels 'teach, that chastity is only individual attachment; that no duty exists which is not prompted by feeling; that impulse is the main spring of virtuous actions, while laws and religion are only unjust restraints' (Strictures 1: 35; ch. 1). All More's criticisms about sentimental novels reside in their attacks upon the very social institutions (state, church, family) that she is at great pains to justify and preserve. These are the same institutions that Wollstonecraft is anxious to reform as part of the necessary social change, because "Till society be differently constituted, much cannot be expected from education' (Vindication 37).

Wollstonecraft does not object to sentimental novels because they attack institutions but because they attack the concept of female individuality: 
Sensibility is described and praised.... Gallantry is made the only interesting subject with the novelist; reading, therefore, will often co-operate to make his fair admirers insignificant. (Thoughts on the Education of Daughters 49-50)

She believes that the preoccupation of novels with affectations of sensibility, males, or 'gallantry' makes the female herself insignificant. She repeatedly complains throughout the Vindication that

In sermons or novels... Men are allowed by moralists to cultivate, as Nature directs, different qualities, and assume the different characters, that the same passions, modified almost to infinity, give to each individual... but all women are to be levelled, by meekness and docility, into one character of yielding softness and gentle compliance. (212)

This is similar to her criticism that it is too universal a maxim with Novelists, that love is felt but once' (Thoughts on the Education of Daughters 85 ) which once again relegates females to limiting stereotypical behaviour.

I contend that Wollstonecraft's argument that all females are significant both inside and outside the domestic sphere threatens the existing social institutions in a way that More's claim for increased domestic significance within the paternal system does not. 'Women,' Wollstonecraft asserts, are not 'insignificant objects of desire, mere propagators of fools' (Vindication 9), both roles which define the female in relation to the male, in terms of beauty or procreation; women have independent rights that need to be expressed and heard.

Although More and Wollstonecraft both locate poor conversation as a consequence of novel-reading they differ over what constitutes good conversation. More states, 'A talent for conversation should be the result of education, not its precursor' (1: 172; ch. 7) but, unfortunately, 'girls who have been accustomed to devour frivolous books' such as the superficial knowledge of 'Beauties' ('crippled mutilations')

will converse and write with a far greater appearance of skill as to style and sentiment at twelve or fourteen years old, than those of a more advanced age who are under the discipline of severer studies... and those who early begin with talking and writing like women, commonly end with thinking and acting like children. (1: $173 ;$ ch. 7$)$

Such texts encourage a false and early development of a female. This is worrisome to More because conversation is an external indication of internal purity and essential femininity. Young females must guard 
against being misread by males who might mistake any external signs of worldliness with internal corruption. As she explains:

Let [each female] not lament it as a hardship, but account it as a privilege, that the delicacy of their sex impels them more scrupulously to avoid the very appearance of evil, since that very necessity serves to defend their purity by a more deep intrenchment [sic] from the evil itself. (Strictures 2: 40; ch. 13)

Since a patriarchal society dictates that a female's value depends upon her chastity, purity and submission - none of which are easy to exhibit in public - any ostentatious display of wit or learning might suggest internal corruption.

In direct contrast, Wollstonecraft writes on the subject of conversation:

Reading of novels makes women, and particularly ladies of fashion, very fond of using strong expressions and superlatives in conversation; and, though the dissipated artificial life which they lead prevents their cherishing any strong legitimate passion, the language of passion in affected tones slips forever from their glib tongues, and every trifle produces those phosphoric bursts which only mimic in the dark the flame of passion. (Vindication 432)

Wollstonecraft's criticisms about the inappropriate use of 'strong expressions' and the 'language of passion' lie in the fact that because of the 'dissipated artificial life [females] lead' they do not experience the real thing but 'only mimic the dark flame of passion.' (More rejects both the suggestion that females have any rights to experience strong passions or that they are an appropriate subject for female educational treatises.) Wollstonecraft's political beliefs lead her to be more voluble about Women's Rights which include the right to experience passion first hand rather than secondhand through reading tales of romance and sentiment. Not that she suggests that females should imitate fiction, but more subtly that living through fiction prevents life itself. Instead of cultivating innocence Wollstonecraft urges them to cultivate its very opposite - 'the treasure of life, experience' (59). Experience in general means education and exposure to the vicissitudes of life, a position of knowledge if not of mastery. Wollstonecraft is not always comfortable with the subject but despite her own anxieties (some of which are discussed in Poovey 48-113), especially in the Vindication of the Rights of Woman and her fragment The Wrongs of Woman; or, Maria she does voice the problem in an effort, however tenuous, to legitimise female desire.

Thus More and Wollstonecraft identify similar drawbacks to the popular practice of novel reading and reading in general among females but for widely different reasons. More wants a female to read appropri- 
ate texts that teach her to be a better mother, sister, relative and Christian social member, rather than to waste her time pursuing idle entertainments. More distrusts any reading material that suggests a female is superfluous and has no real social influence but advocates texts that adequately teach her how to fulfil her domestic role. She especially warns the female reader away from novels for fear that they will corrupt her and lead to inappropriate social behaviour. Her fictional and non-fictional works reinforce the underlying belief in the natural differentiation of the sexes and bolster the existing social order. Like other anti-Jacobins, More uses the written word to teach the reader into accepting 'things as they are'; and although such writers invest a female's social role with moral significance it constitutes part of the vindication of the patriarchal order.

As an English-Jacobin writer Wollstonecraft also despises ornamental females and uses her works to campaign for a newly constituted society. To achieve this she tries to teach females how to read (whether a novel or an educational treatise) carefully. Wollstonecraft, however, wants a female to read texts that encourage her to believe in her own self worth, mental capabilities and sense of autonomy. She accepts that education itself is a dangerous but necessary process because one cannot learn to think independently without taking certain risks. Wollstonecraft distrusts the undirected perusal of novels because the female reader is too easily misled about her true potential socially, politically, and economically. Education of this nature is not prescriptive but discriminating and liberating. She argues that a female's social role is politically important, and since patriarchy is not the final authority she encourages them to challenge 'things as they are.'

Given the existing social order, fewer texts fulfil Wollstonecraft's requirements than do More's, although both writers agree that most still teach the female reader that mental imbecility is attractive to males and that everything should be performed in relation to males and the desire to please them.

For modern critics to try and unite such disparate viewpoints ignores the historical and textual information available to us. Such simplification aids the modern reader at the expense of the subject matter and falls into the trap of treating all females as part of a cohesive 'sisterhood' sharing common goals and a common political agenda. Such an approach undermines the female sex's right to differ in opinion or style and retain validity. 


\section{Works Cited}

Analytical Review; or, History of Literature, Domestic and Foreign. Ed. Joseph Johnson and Thomas Christie. London: Joseph Johnson, 1788-98.

Berry, Mary. Extracts of the Journals and Correspondence of Miss Berry from the Years 17831852. 3 vols. Ed. Lady Theresa Lewis. London: Longmans and Green, 1865.

Browne, Alice. The Eighteenth-Century Feminist Mind. Detroit: Wayne State University Press, 1987.

Hays, Mary. The Memoirs of Emma Courtney. 1796. 2 vols. Ed. Gina Luria. New York: Garland, 1974.

Kowaleski-Wallace, Elizabeth. Their Fathers' Daughters: Hannah More, Maria Edgeworth, and Patriarchal Complicity. Oxford: Oxford University Press, 1991.

Mellor, Anne K. Romanticism and Gender. New York: Routledge, 1993.

Moore, Jane. 'Promises, Promises: The Fictional Philosophy in Mary Wollstonecraft's Vindication of the Rights of Woman.' The Feminist Reader: Essays in Gender and the Politics of Literary Criticism. Ed. Catherine Belsey and Jane Moore. London: Macmillan, 1989. 155-74.

More, Hannah. Essays on Various Subjects, Principally Designed for Young Ladies. London: J. Wilkie and T. Cadell, 1777.

-. Strictures on the Modern System of Female Education: With a View of the Principles and Conduct Prevalent among Women of Rank and Fortune. 2 vols. London: T. Cadell and W. Davies, 1799.

-. Memoirs of the Life and Correspondence of Mrs. Hannah More. 2 vols. Ed. William Roberts. New York: Harper, 1836.

Myers, Mitzi. '"Reform or Ruin”: A Revolution in Female Manners.' Studies in EighteenthCentury Culture 11 (1982): 199-216.

Newman, Gerald. 'Anti-French Propaganda and British Liberal Nationalism in the Early Nineteenth Century: Suggestions Toward a General Interpretation.' Victorian Studies 18 (1975): 385-418.

Poovey, Mary. The Proper Lady and the Woman Writer: Ideology as Style in the Works of Mary Wollstonecraft, Mary Shelley and Jane Austen. Chicago: University of Chicago Press, 1984.

Taylor, John Tinnon. Early Opposition to the English Novel: The Popular Reaction from 17601830. New York: King's Crown Press, 1943.

Todd, Janet M. The Sign of Angellica: Women, Writing and Fiction, 1660-1800. London: Virago, 1989.

Wollstonecraft, Mary. A Vindication of the Rights of Woman: with Strictures on Political and Moral Subjects. London: Joseph Johnson, 1792.

-. Thoughts on the Education of Daughters: with Reflections on Female Conduct in the More Important Duties of Life. London: Joseph Johnson, 1787.

-. The Wrongs of Woman: or, Maria. A Fragment. 1797. Ed. Gary Kelly. Oxford: Oxford University Press, 1987. 